\title{
MENINGKATKAN HASIL BELAJAR SISWA MELALUI BRAIN GYM
}

\author{
Akhmad Sukri ${ }^{1}$, Elly Purwanti ${ }^{2}$ \\ ${ }^{1}$ Institut Keguruan dan Ilmu Pendidikan Mataram \\ ${ }^{2}$ Universitas Muhammadiyah Malang \\ email: sukri bio04@yahoo.co.id
}

\begin{abstract}
ABSTRAK
Hasil belajar merupakan perubahan perilaku subyek didik yang mencakup bidang kognitif, afektif, dan psikomotor setelah menerima pengalaman belajarnya. Hasil belajar dapat dijadikan sebagai tolok ukur keberhasilan dalam suatu pembelajaran. Salah satu cara yang dapat dilakukan untuk meningkatkan hasil belajar siswa adalah dengan senam otak atau Brain Gym. Senam otak adalah serangkaian latihan gerak sederhana untuk memudahkan kegiatan belajar dan penyesuaian dengan tuntutan sehari-hari yang bertujuan untuk menyatukan pikiran dan tubuh. Dengan gerakan-gerakan Brain Gym dapat diambil potensi belajar yang terpendam di dalam tubuh melalui pengangktifan dan memaksimalkan kedua fungsi belahan otak sehingga terintegrasi dan bekerja dengan baik. Penerapan Brain Gym dalam pembelajaran di kelas dapat dilakukan pada saat sebelum pembelajaran berlangsung atau tahapan pendahuluan, selama proses pembelajaran berlangsung atau tahapan kegiatan inti, dan setelah pembelajaran diberikan atau tahapan penutup. Dengan Brain Gym diharapkan hasil belajar siswa (kognitif, afektif, dan psikomotor) akan menjadi meningkat.
\end{abstract}

\section{PENDAHULUAN}

Hasil belajar berdasarkan teori Gagne dibagi menjadi beberapa bagian yaitu, 1) keterampilan-keterampilan intelektual, 2) strategi-strategi kognitif, 3) informasi verbal, 4) sikap-sikap, dan 5) keterampilanketerampilan motorik (Dahar, 1988). Namun, apabila dicermati dari kelima hasil belajar tersebut, maka dapat dibagi menjadi 3 aspek utama, yaitu tiga hasil belajar yang bersifat kognitif, satu bersifat afektif dan satu lagi bersifat psikomotor, atau dalam istilah Bloom (1956) disebut sebagai domain kognitif, domain afektif, dan domain psikomotor. Ketiga hasil belajar tersebut merupakan hal yang sangat penting dalam suatu proses pembelajaran, bahkan merupakan tujuan yang harus dicapai dalam pembelajaran. Hasil belajar merupakan perubahan perilaku subyek didik yang mencakup bidang kognitif, afektif, dan psikomotor setelah menerima pengalaman belajarnya (Hamalik, 1995; Sudjana, 2005).
Hasil belajar peserta didik tidak hanya berkaitan dengan kemampuan peserta didik dalam menyerap dan memahami bahan kajian yang diajarkan, namun juga bagaimana perubahan sikap terhadap temannya, keluarga, sosial, dan lingkungan sekitar serta keterampilan yang dicapai setelah mereka belajar. Oleh karena itu, hasil belajar dapat dijadikan sebagai tolok ukur keberhasilan dalam suatu pembelajaran. Indikator yang dapat dijadikan tolok ukur keberhasilan kegiatan belajar tidak hanya berkaitan dengan bertambahnya pengetahuan siswa (Djamarah, 2000) ataupun daya serap terhadap pelajaran sehinggga mencapai prestasi tinggi, baik individu maupun kelompok (Usman, 1993), tetapi juga berkaitan dengan sikap (Usman, 1993), dan keterampilan mereka.

Muhfahroyin (2009) mengutip dari Subrata (1988), membagi faktor yang mempengaruhi hasil belajar menjadi dua, yaitu faktor internal dan faktor eksternal. Faktor 
internal meliputi sikap, minat, motivasi, dan kemampuan peserta didik, sedangkan faktor eksternal meliputi lingkungan, fasilitas, dan proses pelaksanaan pembelajaran. Lebih lanjut dijelaskan bahwa faktor lain seperti kesegaran jasmani, perhatian, dan intelegensia (kemampuan akademik) mempunyai peran yang besar bagi hasil belajar. Selain itu, Syah (2002) membagi faktor yang mempengaruhi hasil belajar menjadi tiga faktor yaitu faktor internal, eksternal dan faktor pendekatan belajar. Faktor internal dibagi menjadi dua aspek, yaitu aspek fisologis seperti kondisi kesehatan, daya pendengaran, penglihatan dan sebagainya, dan aspek psikologis seperti kondisi rohani peserta didik, intelegensi, sikap, bakat, minat dan motivasi. Selain itu, faktor eksternal dibagi menjadi dua yaitu, lingkungan sosial seperti guru, staf administrasi, teman kelas, teman bermain, orang tua dan keluarga peserta didik, sedangkan lingkungan non sosial terdiri dari gedung sekolah dan letaknya, rumah peserta didik dan letaknya, keadaan cuaca dan waktu belajar peserta didik.

Ketika hasil belajar pesereta didik rendah, maka seringkali yang menjadi salah satu alasan penyebabnya adalah guru yang tidak menerapkan metode pembelajaran yang baik, sehingga membuat pembelajaran menjadi monoton yang menyebabkan minat, dan motivasi belajar peserta didik menjadi rendah. Oleh karena itu, banyak penelitian yang mengungkapkan efektivitas penggunaan beberapa metode pembelajaran inovatif untuk meningkatkan hasil belajar siswa seperti metode Think Pair Share dan Reciprocal Teaching (Ismiati, 2011), Student Teams Achievement Division (Rian, dkk, 2012), Teams Games Tournamen (Masriani, 2011), Numbered Head Together (Kusumojanto dan Herawati, 2009), Jigsaw (Supriono, 2006), Pembelajaran berbasis masalah (Handayani dan Sapir, 2009), dan Group-To-Group Exchange
(Aprilia dan Supardiyono, 2012), serta beberapa metode pembelajaran lainnya. Penerapan beberapa metode pembelajaran inovatif diharapkan dapat meningkatkan hasil belajar siswa. Namun, yang perlu dicermati bahwa guru merupakan salah satu faktor dari sekian banyak faktor yang dapat mempengaruhi hasil belajar siswa. Salah satu faktor yang tidak banyak mendapat perhatian adalah aspek psikologis seperti kondisi rohani peserta didik. Kondisi rohani peserta didik yang dimaksudkan adalah kondisi mental peserta didik sebelum menerima pembelajaran atau selama proses pembelajaran berlangsung. Kondisi mental juga memegang peranan penting dalam meningkatkan hasil belajar siswa. Ketika peserta didik dalam keadaan stress atau tertekan, maka otak akan bereaksi dengan menghambat transmisi informasi yang bersifat simultan, akibatnya salah satu belahan otak akan mengalami switched off, sehingga akan terjadi masalah dalam koordinasi dan gangguan terhadap kemampuan untuk berpikir jernih, memecahkan masalah, kemampuan komprehensi, organisasi dan komunikasi secara efektif (Sularyo dan Handryastuti, 2002). Oleh karena itu, proses belajar, berpikir, kreatifitas dan kecerdasan tidah hanya melibatkan otak tetapi juga seluruh tubuh. Sensasi, gerakan, emosi, dan fungsi otak semua bersumber pada tubuh, sehingga diperlukan suatu sistem yang bisa menghubungkan akal (mind) dan tubuh (body) yaitu dengan senam otak atau Brain Gym.

Salah satu cara yang dapat dilakukan untuk meningkatkan hasil belajar siswa dapat melalui senam otak atau Brain Gym. Senam otak merupakan kumpulan gerakan-gerakan sederhana yang bertujuan menghubungkan atau menyatukan akal dan tubuh (Sularyo dan Handryastuti, 2002). Gerakan-gerakan dalam senam otak dapat mengakses kedua belahan otak secara simultan, belahan otak akan 
kembali switched on dan berada dalam kondisi terintegrasi. Penerapan senam otak dalam proses pembelajaran dapat dilakukan pada semua jenjang pendidikan, tidak memerlukan biaya yang mahal, dan mudah dilakukan. Selain itu, penerapan senam otak dapat dikombinasikan dengan seluruh metode pembelajaran yang ingin diterapkan guru di kelas, sehingga dengan adanya kombinasi ini diharapkan dapat meningkatkan hasil belajar siswa.

\section{SENAM OTAK (BRAIN GYM)}

Senam otak atau Brain Gym merupakan serangkaian gerakan tubuh yang dikembangkan oleh Edu-K yaitu singkatan dari Educational Kinesiology. Kinesiologi berasal dari kata Yunani "kinesis" yang berarti gerakan, sehingga kinesiologi diartikan sebagai ilmu tentang gerakan tubuh manusia. Educational Kinesiology adalah ilmu tentang gerakan tubuh dalam pendidikan. $E d u-K$ pertama kali dikembangkan oleh Paul E. Dennison seorang pendidik dan pelopor penelitian otak berkebangsaan Amerika bersama istrinya Gail E. Dennison seorang mantan penari (Demuth, 2005). Lebih lanjut Demuth menjelaskan bahwa pendekatan dasar Educational Kinesiology sebagai metode belajar adalah menarik keluar potensi belajar yang terpendam melalui gerakan tubuh. Hal ini didasari karena pada tubuh manusia terpendam energi dan potensi yang dapat diaktifkan dengan gerakan dan sentuhan yang cukup sederhana yang dapat meningkatkan daya belajar, mengintegrasi bagian-bagian otak yang selama ini belum bekerja sama dengan baik, serta mendukung penyembuhan berbagai penyakit psikis, somatis, dan psiko-somatis.

Senam otak (Brain Gym) adalah serangkaian latihan gerak sederhana untuk memudahkan kegiatan belajar dan penyesuaian dengan tuntutan sehari-hari (Demuth, 2005) yang bertujuan untuk menyatukan pikiran dan tubuh (Sularyo dan Handryastuti, 2002). Senam otak memiliki 26 gerakan yang mencakup tiga dimensi otak yaitu, lateralis, pemfokusan, dan pemusatan (Dennison dan Dennison, 2005). Dimensi lateralis untuk belahan otak kiri dan kanan yang bertujuan untuk melatih koordinasi tubuh kiri-kanan, dimensi pemfokusan untuk bagian belakang otak, batang otak dengan bagian depan otak, sedangkan dimensi pemusatan untuk menyeimbangkan posisi depan dan belakang (sistem limbi) serta otak besar untuk koordinasi tubuh atas dan bawah.

Beberapa alasan dikemukakan terhadap perlunya melakukan senam otak, yaitu (1) orang yang sulit belajar berusaha terlalu keras, sehingga terjadi stres si otak, (2) mekanisme integrasi otak melemah, sehingga bagianbagian otak tertentu kurang berfungsi, (3) informasi yang diterima di otak bagian belakang sulit diekspresikan, sehingga orang merasa kurang berhasil dan stres yang mengakibatkan semangat belajar atau bekerja berkurang, dan (4) orang yang kurang belajar dan berusaha, prestasinya statis bahkan menurun dan perasaan tidak berhasil semakin bertambah, sehingga sulit untuk keluar dari lingkungan negatif tersebut (Demuth, 2005).

Sularyo dan Handryastuti (2002), menuliskan bahwa ada beberapa manfaat yang diperoleh ketika melakukan senam otak, yaitu (1) memperbaiki kemampuan membaca, mengeja, komprehensi, menulis tangan dan membuat tulisan, (2) memperbaiki kepercayaan diri, koordinasi dan komunikasi, (3) memperbaiki konsentrasi dan memori, (4) memperbaiki hiperaktifitas, (5) mengatasi stres dan mencapai suatu tujuan, (6) meningkatkan motivasi dan mengembangkan kepribadian, (7) meningkatkan keterampilan organisasi, dan (8) memperbaiki penampilan. Lebih lanjut Eliasa (2007), mengemukakan keuntungan yang 
diperoleh dengan senam otak, bahwa dengan senam otak hasil akan segera dirasakan dalam hal kemandirian anak dalam belajar dan seseorang dalam bekerja, serta secara aktif meningkatkan potensi dan keterampilan yang dimiliki karena senam otak menyenangkan dan menyehatkan.

\section{MENINGKATKAN HASIL BELAJAR SISWA DENGAN SENAM OTAK (BRAIN GYM)}

Penerapan metode pembelajaran yang bervariatif di dalam kelas perlu untuk dilakukan oleh seorang guru, supaya pembelajaran menjadi lebih menarik, sehingga siswa akan termotivasi untuk belajar. Djamarah dan Zain (2010), mengungkapkan bawah metode pembelajaran yang digunakan guru di dalam kelas sebaiknya tidak hanya terpaku pada satu metode saja namun beberapa metode sehingga pembelajaran tidak menjadi membosankan. Tentu saja, penggunaan metode pembelajaran tersebut harus tepat melihat situasi dan kondisi yang mendukung dan faktor psikologis anak didik. Dengan demikian, penerapan metode-metode pembelajaran ini diharapkan dapat meningkatkan minat, motivasi dan kesadaran anak didik yang pada akhirnya dapat meningkatkan hasil belajar mereka. Namun, penggunana metode pembelajaran ini merupakan salah satu faktor yang mempengaruhi hasil belajar siswa, faktor lain yang kurang mendapat perhatian adalah faktor psikologis yaitu mental anak didik seperti stres, kurang berkonsentrasi, daya ingat yang lemah, dan sebagainya harus siperhatikan dalam pembelajaran. Oleh karena itu, hal ini perlu disiapkan sebelum, selama, atau sesudah pembelajaran dilakukan. Faktor mental ini sangat penting karena dipengaruhi oleh kerja otak yang saling terintegrasi, bukan hanya dimensi psikis, namun juga keseluruhan fungsi dari tubuh dikontrol oleh otak (Sularyo dan Handryastuti, 2002).

Senam otak atau Brain Gym dapat dilakukan untuk mengeksploitasi segala potensi belajar melalui gerakan-gerakan tubuh (Demuth, 2005). Senam otak dapat dilakukan pada semua jenjang pendidikan mulai dari tingkatan taman kanak-kanak, sekolah dasar, sekolah menengah, bahkan sampai pada tingkatan perguruan tinggi. Tidak hanya itu, senam otak selain digunakan untuk kalangan akademis tetapi juga dapat digunakan oleh kalangan kalangan bisnis, serta sebagai alat untuk pertumbuhan personal. Dalam pembelajaran, senam otak dapat dikombinasikan dengan penggunaan metode pembelajaran yang lain, karena senam otak tidak terpaku dengan penggunaan metode belajar. Sebagai salah satu alternatif penggunaan senam otak dalam kegiatan pembelajaran dapat dilakukan pada tiga bagian kegiatan pembelajaran di kelas yaitu pada saat sebelum pembelajaran atau pendahuluan, pada saat pembelajaran berlangsung atau kegiatan inti, dan pada saat pembelajaran telah selesai atau penutup. Alternatif lain yang dapat dilakukan adalah melakukan seluruh gerakan senam otak (Brain Gym) sebelum guru masuk ke dalam kegiatan pembelajaran baik kegiatan pendahuluan, kegiatan inti dan kegiatan penutup. Dalam artikel ini penulis menyajikan penggunaan senam otak dalam kegiatan pembelajaran yang dilakukan sebelum, selama dan setelah kegiatan pembelajaran berlangsung.

1. Sebelum

Pembelajaran/Kegiatan

\section{Pendahuluan}

Kegiatan pendahuluan dalam pembelajaran dilakukan terutama untuk menciptakan suasana awal pembelajaran berupa kegiatan untuk pemanasan. Pada tahap ini dapat dilakukan penggalian terhadap pengalaman anak tentang materi yang akan 
dibelajarkan oleh guru. Tahapan ini membutuhkan kesiapan konsenstrasi yang tinggi, kesiapan seluruh panca indera, dan minat serta motivasi yang tinggi dari siswa. Oleh karena itu, gerakan senam otak atau Brain Gym yang dapat dilakukan adalah pijat kuping (Gambar 1). Gerakan ini dengan memijat daun telinga dari atas ke bawah. Gerakan ini dapat meningkatkan kemampuan pendengaran, keseimbangan, daya pikir dan daya ingat (Demut, 2005), keterampilan berpikir abstrak dan memori jangka pendek (Sularyo dan Handryastuti, 2002). Selain itu, siswa juga dapat melakukan gerakan gerak diagonal (Gambar 2), dan pernapasan perut (Gambar 3). Dalam kegiatan ini juga memungkinkan untuk melakukan gerakan-gerakan yang lain, namun yang perlu diperhatikan juga masalah waktu yang terbatas untuk kegiatan pembelajaran. Keseluruhan gambar dalam artikel ini diambil dari Demut (2005) dan Sularyo dan Handryastuti

(2002).

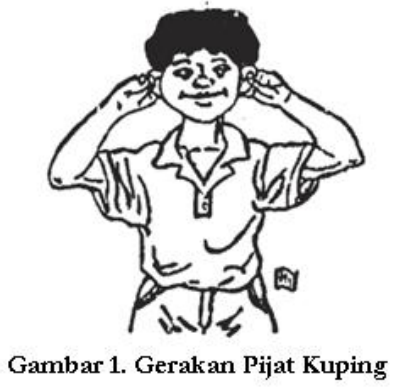

2. Saat Pembelajaran Berlangsung/Kegiatan Inti

Kegiatan ini biasanya diisi oleh guru dengan penyampaian materi pembelajaran. Dalam kegiatan ini, senam otak dapat diberikan disela-sela kegiatan pembelajaran, misalnya pada saat siswa selesai mengerjakan lembar kerja siswa yang diberikan oleh guru, sesaat sebelum guru melanjutkan ke materi berikutnya atau disela-sela sintaks pembelajaran yang diterapkan oleh guru. Dalam hal ini, guru dituntut untuk bisa mengatur jam pembelajaran yang telah disiapkan yang akan dipergunakan sebaikbaiknya termasuk dalam melakukan senam otak atau Brain Gym. Gerakan senam otak
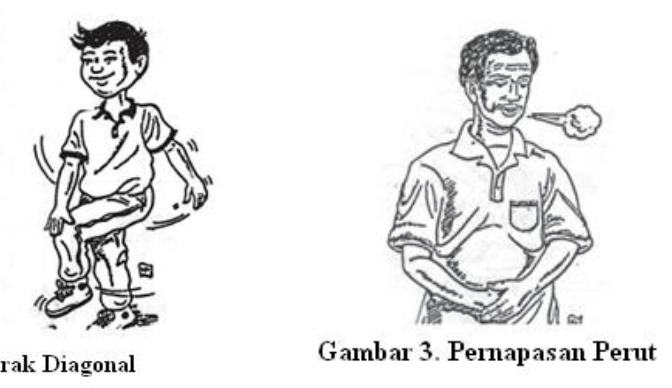

yang bisa dilakukan pada kegiatan ini adalah gerakan-gerakan yang dapat meningkatkan oksigen ke dalam otak, meregangkan otot-otot yang sudah kaku baik itu leher, bahu, dada, tubuh bagian belakang, sendi-sendi bagian belakang kaki dan sebagainya. Gerakangerakan ini diperlukan untuk meningkatkan kemampuan komunikasi, konsentrasi, mendengar, berpikir, menyelesaikan pekerjaan, kemudahan menulis dengan tangan, mengucap dan menulis kreatif. Gerakan-gerakan yang dapat dilakukan adalah kepala kobra (Gambar 4), burung hantu (Gambar 5), mengaktifkan tangan (Gambar 6), melenturkan sendi kaki (Gambar 7), bandul gravitasi (Gambar 8) dan pijat otot menguap (Gambar 9). 

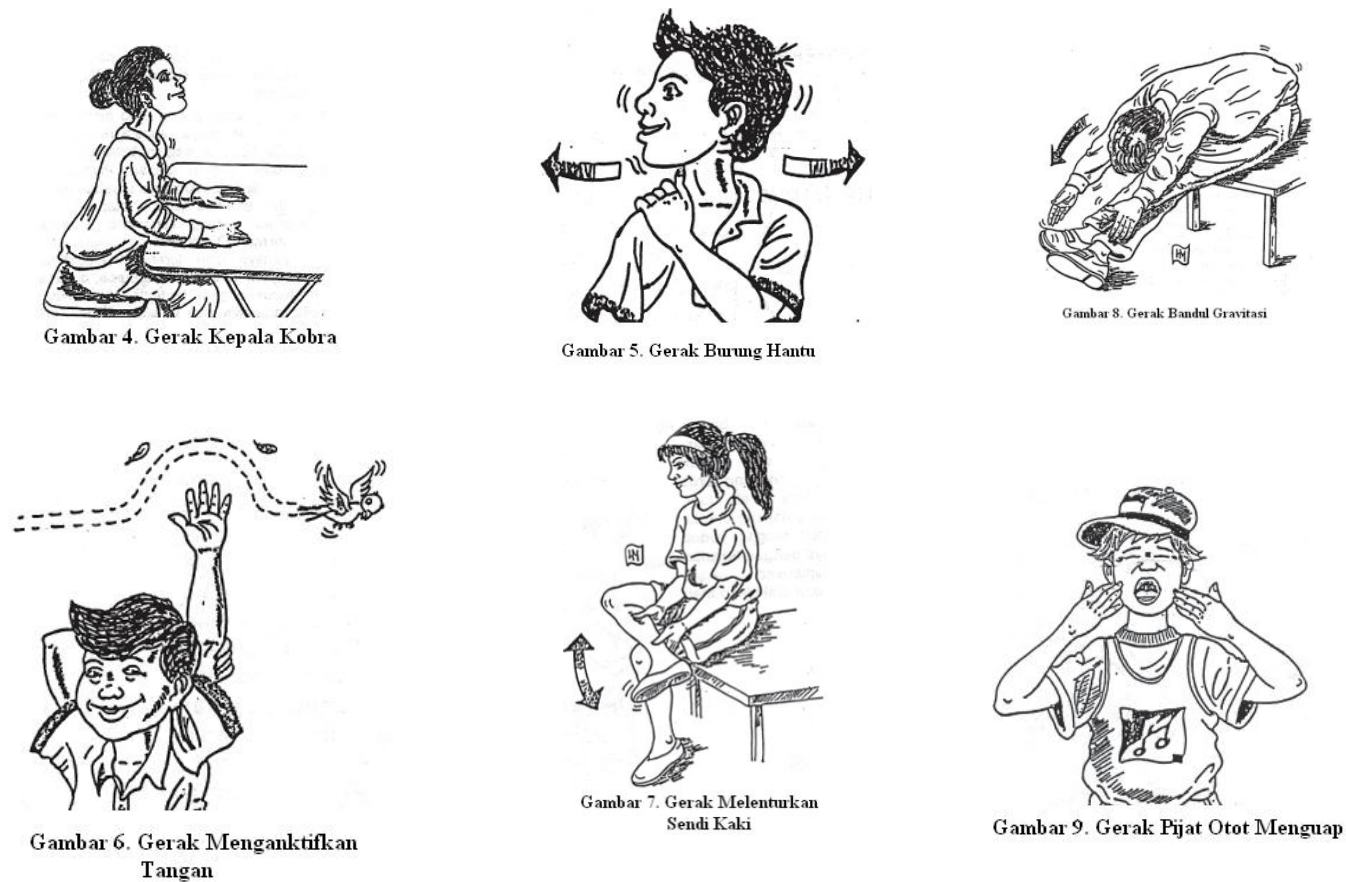

\section{Setelah Kegiatan Pembelajaran/Penutup}

Pada tahapan ini, guru menyampaikan kembali ringkasan materi pembelajaran, memberikan penguatan-penguatan kepada siswa serta memberikan arahan mengenai halhal apa yang harus dilakukan untuk menghadapi materi berikutnya atau memberikan tugas rumah kepada siswa. Pada saat ini siswa berada dalam keadaan konsentrasi penuh, dan otot-otot masih tegang
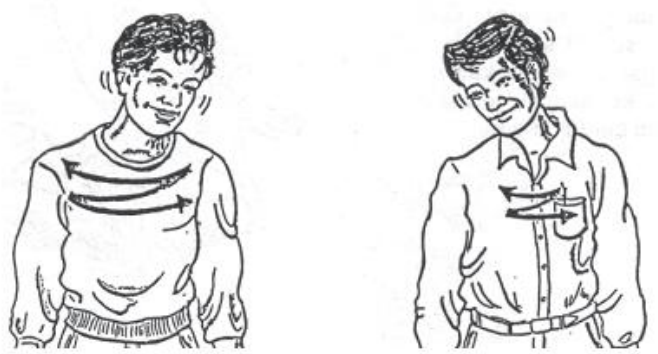

Gambar 10. Gerak Putar Kepala sehabis melakukan pembelajaran, oleh karena itu perlu diregangkan yang akan membuat siswa menjadi santai dan melepas semua kepenatan setelah belajar. Gerakan-gerakan senam otak dapat dilakukan sesaat sebelum pembelajaran usai. Gerakan-gerakan yang dapat dilakukan adalah putar kepala (Gambar 10), tombol bumi (Gambar 11), dan titik positif (Gambar 12).
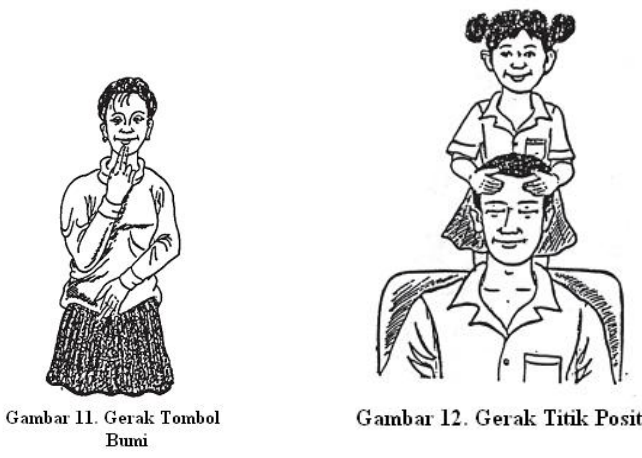

Gambar 12. Gerak Titik Positif 
$\begin{array}{cccc}\text { Penerapan } & \text { Brain } & \text { Gym dalam } \\ \text { pembelajaran di kelas diharapkan } & \text { dapat }\end{array}$ meningkatkan prestasi belajar siswa melalui pengaktifan kedua belahan otak sehingga dapat terintegrasi dan bekerja secara maksimal. Terlebih jika dikolaborasikan dengan berbagai metode pembelajaran inovatif, maka akan lebih meningkatkan kesiapan siswa untuk belajar yang pada akhirnya meningkatkan hasil belajar siswa. Hal ini didukung oleh beberapa penelitian tentang Brain Gym yang pernah dilakukan untuk meningkatkan hasil belajar siswa seperti yang dilakukan oleh Khuluqiyah dan Arief (2012), tentang pengaruh penerapan zona alfa dengan kegiatan Brain Gym. Hasil penelitian ini menunjukkan bahwa siswa yang menerapkan zona alfa melalui kegiatan Brain Gym memiliki hasil belajar yang lebih baik daripada hasil belajar siswa yang tidak menerapkan. Selain itu, penelitian yang dilakukan oleh Prihastuti (2009), mengungkapkan bahwa aktivitas Brain Gym dapat memberikan kontribusi dalam meningkatkan hasil tes kecakapan berhitung siswa. Oleh karena itu, penerapan Brain Gym dalam pembelajaran diharapkan bisa dilakukan oleh guru, sebagai salah satu cara untuk meningkatkan hasil belajar siswa.

\section{PENUTUP}

Senam otak (Brain Gym) adalah serangkaian latihan gerak sederhana untuk memudahkan kegiatan belajar dan penyesuaian dengan tuntutan sehari-hari yang bertujuan untuk menyatukan pikiran dan tubuh. Dengan gerakan-gerakan Brain Gym dapat diambil potensi belajar yang terpendam di dalam tubuh melalui pengangktifan dan memaksimalkan kedua fungsi belahan otak sehingga terintegrasi dan bekerja dengan baik. Penerapan Brain Gym dalam pembelajaran di kelas dapat dilakukan pada saat sebelum pembelajaran berlangsung atau tahapan pendahuluan, selama proses pembelajaran berlangsung atau tahapan kegiatan inti, dan setelah pembelajaran diberikan atau tahapan penutup. Dengan Brain Gym diharapkan siswa akan lebih siap belajar, lebih berkonsentrasi, dan melalui Brain Gym dapat meningkatkan hasil belajar siswa baik kognitif, afektif, dan psikomotor.

\section{DAFTAR RUJUKAN}

Aprilia, L.D.,dan Supardiyono. 2012. Penerapan Strategi Group-To-Group Exchange Terhadap Hasil Belajar Siswa Kelas VIII pada Materi Pokok Getaran dan Gelombang di SMP Negeri 2 Sugio Lamongan, Inovasi Pendidikan Fisika, Vol 1(1): 36-43.

Bloom, B.S. 1956. Taxonomy of Educational Objectives: The Classification of Educational Goals. London: David McKay Company, Inc.

Dahar, R.W. 1988. Teori-Teori Belajar. Jakarta: DITJEN DIKTI, Departemen Pendidikan Nasional.

Djamarah, S.B.,dan Zain, A. 2010. Strategi

Belajar Mengajar. Jakarta: Rineka Cipta.

Demuth, E. 2005. Meningkatkan Potensi Belajar Melalui Gerakan dan Sentuhan: Sebuah Pengantar dan Pedoman Dasar "Edu-K" dan "Brain-Gym", INTIM, No 8: 103-112.

Dennison, P.E.,dan Dennison, G.E. 2005. Brain Gym Simple Activities for Whole Brain Learning. USA: EduKinesthetics, Inc.

Eliasa, E.I. 2007. Brain Gym, Brain Games (Mari Bermain Otak dengan Senam Otak), Makalah Disampaikan dalam Program Parent Volunteer's Week di SD Budi Mulia Dua Yogyakarta, 26-27 Desember.

Hamalik, O. 1995. Kurikulum dan pembelajaran. Jakarta: Bumi Aksara. 
Handayani, S.,dan Sapir. 2009. Efektifitas

Penerapan Model Pembelajaran

Berbasis Masalah (Problem Based

Learning) dan Pembelajaran

Kooperatif (Cooperative Learning)

Tipe Jigsaw untuk Meningkatkan

Aktivitas Belajar, Hasil Belajar dan

Respon Belajar Siswa pada Mata

Pelajaran Ekonomi di SMA Negeri 2

Malang, JPE, Vol 2(1): 38-51.

Ismiati, L. 2011. Pengaruh Strategi Belajar TPS, Reciprocal Teaching, dan Integrasinya terhadap hasil Belajar Kognitif dan Kemampuan Berpikir Kritis Peserta Didik Berkemampuan Akademik Berbeda di R-SMA-BI Batu. Tesis tidak Diterbitkan. Malang: Universitas Negeri Malang.

Khuluqiyah, K.,dan Arief, A. 2012. Pengaruh Penerapan Zona Alfa dengan Kegiatan Brain Gym Terhadap Hasil Belajar Siswa Pada Materi Alat-Alat Optik di Kelas VIII SMP Islam Krembung Sidoarjo, Inovasi Pendidikan Fisika, Vol 1(1): 9-15.

Kusumojanto, D.D.,dan Herawati, P. 2009. Penerapan Pembelajaran Kooperatif Model Numbered Head Together (NHT) untuk Meningkatkan Hasil Belajar Siswa pada Mata Diklat Manajemen Perkantoran Kelas X APK di SMK Ardjuna 01 Malang, Jurnal Penelitian Kependidikan, Vol 19 (1): 83-98.

Masriani, 2011. Pengaruh Penerapan Model Pembelajaran Kooperatif Tipe Teams game Tounament (TGT) Terhadapa Hasil Belajar Siswa SMP Negeri 21 Palu, Jurnal Biodidaktis, Vol 5(1): 2934.
Muhfahroyin, 2009. Pengaruh Strategi Pembelajaran Integrasi STAD dan TPS dan Kemampuan Akademik terhadap Hasil belajar Kognitif Biologi, Kemampuan Berpikir Kritis, dan Keterampilan Proses pada Siswa SMA di Kota Metro. Disertasi tidak diterbitkan. Malang: Universitas Negeri Malang.

Prihastuti. 2009. Pengaruh Brain Gym Terhadap Peningkatan Kecakapan Berhitung Siswa Sekolah Dasar, Cakrawala Pendidikan, Vol 28(1): 3547.

Rian, M.B.,Asnawati, R.,\& Sutiarso, S. 2012. Pengaruh Pembelajaran Kooperatif Tipe STAD Terhadap Hasil Belajar Matematika Siswa, Jurnal Pendidikan Matematika, Vol 1 (4): 233-237.

Sudjana, Nana. (2005). Dasar-Dasar Proses

Belajar Mengajar. Bandung: Sinar

Baru Algensindo.

Sularyo, T.S.,dan Handryastuti, S. 2002. Senam Otak, Sari Pediatri, Vol 4(1): $36-44$.

Supriono. 2006. Penerapan Metode

Pembelajaran Kooperatif Model

Jigsawa dalam Pembelajaran

Pendidikan Kewarganegaraan, Jurnal Pendidikan Inovatif, Vol 2(1): 19-23.

Syah, M. 2002. Psikologi Pendidikan dengan

Pendekatan Baru. Bandung: PT. Remaja Rosdakarya.

Usman, A.T. 1993. Proses Belajar Mengajar yang Efektif. Bandung: Bina Budhaya.

Winkel, W.S . 2005. Psikologi Pengajaran. Jakarta: PT Gramedia Pustaka Utama. 